\title{
大阪湾に渡来する稀なるシギ・チドリ類に就て(1) On some rare waders (Limicolae) recorded from Ōsaka Bay coast
}

\author{
小林. 桂 助 \\ Keisuke Kobayashi
}

私は 1950 年 1 月以降本年 (1954 年) 6 月に至る 4 年半の間, 大阪湾の 大和川河口部に近い南港埋立地並にその附近に於て, シギ・チドリ類の調查 を続けて来た。

南港埋立地は住吉川と大和川とに狭まれた住吉浦の先端に位する方的 1 籸 の埋立地であり，南港橋に依つて陸地と連絡されている。1940 年頃より大阪 港の趠長としてサンドポンプに依つて土を盛り上げて理立を開始, 1941 年 8 月漸く南港橋から 300 米迄の埋立が完成した時には既に大阪港防備の高射砲 隊亚に哨空隊の陣地として砲列が敷かれ，バラック兵舍が建ち並んだ。埋立 は其淩も続けられ 1942 年頃, 漸く現在の形が完成したが, 当時は一般人の 入場を許されぬままに終戦を迎えたのである。敗戦によつて兵隊の立去つた あとの兵舍は漁夫の宿舍に利用されていたが，1950 年 9 月 3 日のジエー ン台風の為, バラツクは一瞬にして破壊流失, 逃げ遅れた婦女子14名の貴い 犠牲者さえ出している。

大阪市とその附近を流れて大阪湾に流入する各河川は上流より土砂を流し て河床は年ふ亶くなり，反効に河口部一带に於ては土地は年及沈下して行く 傾问がある。1948 年著者が初めて南港を訪れた時と今日とでは满潮線の位 琶によつても，埋立地が明に沛下している事を認める事が出来る程である。

干潮侍には南港埋立地の北側半分程は干潟となつてあらわれるが，満潮持 には滿ぶと海水をたたえた入江となる椂な事は 1948 年当時には見る事が出 来なかつた現象である。

サンドポンプで埋立した上に石炭款を積み一段と高くなつた東側と南側約 半分はセツカやヒバリの多数棲息するチガヤ・カニツリグサ・ススキの原野 
となつているが，西方に移るに従い土地は低く，埋立てたままの粘土質の湿 原になつて居り，そこには七面草(Suaeda japonica)が一面に繁つている。 この高台と低地との境界のあたりは一段と低地となつて居り，雨水をたたえ て，淡水汁を形成している所が三々所程あり，最大のものでは長さ100 米幅 20米にも及んでいる。空襲待にはこの陣地も爆彈に見舞われ，大形爆彈によ つて穿たれた円形の穴が水溜となつた所も数々所ある。これ等の池の周囲部 には今日ではヨシが樑く生い繁り，カルガモ・バン・ヒクイナ・オオヨシキ リ・ヨシゴイ等の恰好の蕃殖地となつて居り春期と秋期とにはトモエガモ・ ヒドリガモ・シマアジ・オナガガモ等の休息所ともなつている。

海に面した砂と粘土の浜, 南港周辺の所ふに積み上げられたコンクリート 彆の土台石や天然岩石，又北側半分程を占める広大な干潟は，春秋の侯には シギ・チドリ類の絶好の渡来地であり又淡水を好む種類は，前記の淡水池だ の, 七面草の生い繁つた湿原にも集るので, 此処南港一带はシギ・チドリ類 の渡りの調査には誠に適当な所である。

南港橋迄に至る住吉浦には, 戦前には火薬庫が二ケ所あつた。堀と堤防と に低つて囲まれ，附近は一面の臀原と湿性の芜地とで，立入りを許されなか つた所であつたので，此処にも沢山のシギ・チドリ類が渡来した。然し戦後 直ちに火薬庫は取こわされ，萝地や臀原は或は埋立てて製材工場が建ち，又 一・部は更に堀り下げて池となり，住吉川に閘門を開く貯水場として利用され， 環境は全く一变した。今日ではシギ・チドリ類の渡来地には到底なり得ない 所である。

只南港橋によつて劃された南港一伤のみが今侗終戦直後のままの姿で取残 された唯一の地である。従つて附近に渡来するシギ・チドり類は, 今日ではそ の殆んどが南港に集ると云つても過言ではなく，この地えの春秋の渡来を数 量的に調査する上に於ても，大体の趨勢を何い知る事の出来る便宜もある。

この調查は更に継続して，追て稿を改めて結果を発表する積りであるが， 過去四年半の锶察回数は以下の表の示す通り各月を通じて総数 173 回，記録 する事の出来たシギ・チドリ類は下記目録の通り 38 種に及んでいる。

一体シギ・チドリ類は夏羽・冬羽・幼鳥並びにそれ等の中間のもの等，そ れぞれ羽衣を罢にする為，他類の鳥に比し，野外観察には綿密な注意を必要 とする。種類に低つては，採集して標本を手にしなければ，種類を確める事 
の困難なものも多い。調査の正確を期する為, 本篇に取报つた各種は尠く共 年 次別 - 月 別観 察 表

\begin{tabular}{|c|c|c|c|c|c|c|}
\hline & 1950 & 1951 & 1952 & 1953 & 1954 & 合 計 \\
\hline 1 月 & 3 & 1 & 2 & 0 & 1 & 7 \\
\hline 2 月 & 0 & 1 & 1 & 1 & 1 & 4 \\
\hline 3 月 & 5 & 3 & 3 & 2 & 1 & 14 \\
\hline 4 月 & 8 & 6 & 4 & 4 & 4 & 26 \\
\hline 5 月 & 5 & 6 & 4 & $3^{*}$ & 5 & 23 \\
\hline 6 月 & 2 & 3 & 3 & $2^{*}$ & 4 & 14 \\
\hline 7 月 & 1 & 4 & 2 & $3^{*}$ & & 10 \\
\hline 8 月 & 7 & 5 & 6 & 4 & & 22 \\
\hline 9 月 & 8 & 5 & 3 & 4 & & 20 \\
\hline 10 月 & 7 & 3 & 4 & 3 & & 17 \\
\hline 11 月 & 3 & 2 & 2 & 2 & & 9 \\
\hline 12 & 4 & 1 & 1 & 1 & & 7 \\
\hline 合棓 & 53 & 40 & 35 & 29 & 16 & 173 \\
\hline
\end{tabular}

* 印は䈉者外遊中にてこの間の記録は坂根干氏による。

目

録
1) Lobipes lobatus
2) Tringa ocrophus
3) Tringa glareola
4) Tringa incana brevipes
5) Tringa hypoleucos
6) Tringa erythropus
7) Tringa totanus eurhinus
8) Tringa stagnatilis
9) Tringa nebularia
10) Pseudototanus guttifer
11) Xenus cinereus
12) Limosa limosa melanuroides
13) Limosa lapponica baueri

14) Numenius arquata orientalis

15) Numenius madagascariensis

16) Numenius phaeopus variegatus

17) Calidris canutus canutus

18) Calidris tenuirostris

19) Calidris ferruginea

20) Calidris alpina sakhalina

21) Calidris ruficollis ruficollis

22) Calidris minutilla subminuta

23) Calidris acuminata

24) Limicola falcinellus sibirica

25) Crocethia alba

26) Capella gallinago gallinago 
27) Capella megala

28) Rostratula benghalensis benghalensis

29) Squatarola squatarola

30) Charadrius dominicus fulvus

31) Charadrius leschenaultii leschenaultii

32) Charadrius mongolus stegmanii
33) Charadrius alexandrinus dealbatus

34) Charadrius dubius curonicus

35) Vanellus vanellus

36) Himantopus himantopus himantopus

37) Arenaria interpres interpres

38) Glareola pratincola maldivarum

一・回以上は此地に於て自ら採集したもののみである事を附記しておく。

倘以上の他，採集する事方出来なかつた為に本目録から除外したが，エリ マキシギ? Philomachus pugnax (2 of or 2 juv.? 1954 年 6 月 27 日観 察) コシギ? Lymnocryptes minima（1950 年 9 月 24 日 2 羽一本種は 伊丹昆陽池に於て 1951 年 10 月 30 日及 1952 年 10 月 22 日に各 1 羽宛 採集された記録がある。) 等が観察され, 又 Jahn 氏はへラシギ Eurynor hynchus pygmeus を(1940 年 9 月 22 日) 観祭して居られる。又ケリ Microsarcops cinerea やオジロトウネン Calidris temminckii 当伊丹の 昆陽池附近では少数乍ら年々見られる種類であるから，南港に於ても海岸に 近い池や湿原では将来採集される可能性のある種類である。今後数年に亘り この調查を継続すれば更に種類を增す事と思われるが，とりあえず本篇には 上記目録中，從来日本各地よりの宛録の比較的尠いもの9 種類について報告 する事とする。

\section{I. コアオアシシギ Tringa stagnatilis}

钼察及採集。

1953 年 9 月 6 日

1953 年 9 月 13 日

第 1 䅺本。ᄋ juv. 海上を飛翔していた本種 1 羽とアオアシシギ 2 羽と が干潟の水際に着陸した所を採集。

第 2 標本。马 juv. アオアシシギ 1 羽と共に干潟に近い淺い淡水池で採 飭中のもの老採集。

2 羽错察採集。

2 羽観察中 1 羽採集。 
第 3 標本。9 juv. アオアシシギ 1 羽と共に前記と同じ池にて採餴中の ものを採集。他の 1 羽は干潟上空を 4 羽のアオアシシギと共に飛翔していた。 測定

\begin{tabular}{|c|c|c|c|c|c|}
\hline 性 別 & 採集 年 月 日 & 㧘 峰 & 瓷 長 & 跗 蹠 & 尾 長 \\
\hline 우 jev & 1953 年 9 月 6 日 & 43 & 135 & 51 & 57 \\
\hline 우 jev & 同 & 41.5 & 135 & 49 & 55 \\
\hline 우 jev & 1953 年 9 月 13 日 & 42 & 138 & 52 & 56 \\
\hline
\end{tabular}

三点共雃成鳥冬羽に似ているが雨覆冬羽の羽緑黄白色なる点に依つて第一 年目の冬羽と推定される。嘴は荅黒色，脚は暗緑色である。

習 性

野外に於ける習性はアオアシシギと政好て酷似して居り，海浜や淺池に下

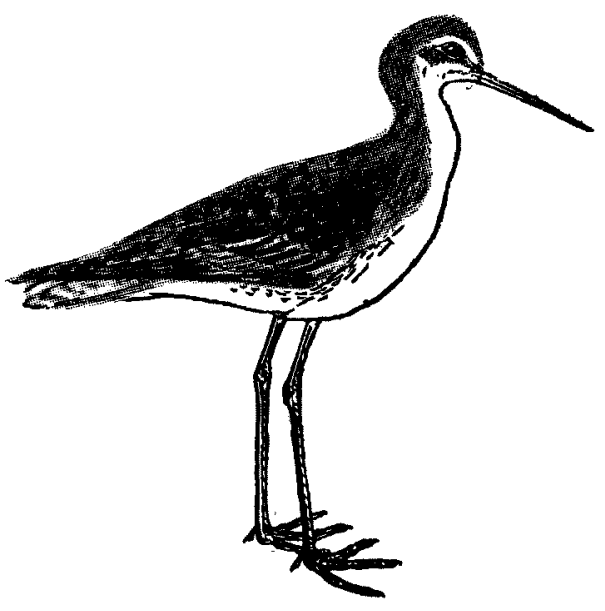

コアオアシシギ冬将

りて居るものは之を一呬り小型 にしただけである。只脚の割合 はアオアシシギより遙に長い。 飛翔時当頸を長く突き出し, 脚 は尾りよ遙に長く後方に延ばし ている。下面と腰の白色が顯著 である。

毎回アオアシシギと共に観察 しているのでその大きさに依つ て直ちに本種を識別する事が出 来だ。椑翔中にも採慨中にも一 回を鳴声をきく事は出来なかつ た。

食性

第一標本より検出した食餌は何れむ小型の巻貝類であり, 京都大学理学部 動物学教室に依頼した同定の結果は次の通りであつた。

ウミミッ゙ゴマツボ (新称) Stenothyra edogawensis (Yokoyama) 83 個 カワグチツボＦluvocingula nipponica Kuroda 1 個 
カワザンショウガイ Assiminea japonica (v. Marteus) 1 個 タマキビＬittorivaga brevicula (Philippi) 7 個

本種が日本から記録されたのは過去に於て只 1 回である。即 1882 年アラ ン・オーストン氏が横浜の市場に於て入手した標本に基いて, ブラキストン 及プライヤー氏が産地横浜附近として記録して以来今日に至る迄日本からは 全く啈告がなかつた。それから約 70 年を経過して初めて第二回目の標本が 採集された事は誠に珍らしい事である。本種は日本には極めて稀に渡来する 鳥であると考えられる。

及日本周辺（旧日本）よりの記録極めて抄く，樺太よりは栄浜（1914年 5 月) 朝鮮よりは京畿道 (1923 年 10 月 5 日) 咸鏡北道 (1917 年 8 月 19 日) 又台湾上りは台南 (1861 年 8 月及 1932 年 12 月 18 日) 等が知られ ているに過ぎない。

份 1953 年の秋には本種は日本各地に渡来したらしく, 上記以外に, 東京 湾千葉浦安の海岸にて㯆川，森岡の両氏が 10 月 11 日に約 20 羽の 1 群を 水田中にて観察され，又9月には小林平一一氏姫路附近白浜海岸にて 1 羽を 観察された由である。

日本から最初の標本が記録されて以来 70 年振に再び比較的数多くのもの が各地で観察されているのは珍らしい事と思う。

\section{II カラフトアオアシシギ Pseudototanus guttifer}

観察及採集。

1954 年 5 月 40 日 1 羽観察採集

测定

\begin{tabular}{|c|c|c|c|c|c|}
\hline 性 別 & 埰集年月日 & 峰 & 長 & 䟷 踥 & 尾 \\
\hline 웅 & 1954年 5 月30日 & $55 \mathrm{~mm}$ & $168 \mathrm{~mm}$ & $46 \mathrm{~mm}$ & $69 \mathrm{~mm}$ \\
\hline
\end{tabular}

冬羽の籸にて卵巢の測定は $9 \mathrm{~mm} \times 5 \mathrm{~mm}$, 最大卵の直径は $2 \mathrm{~mm}$ であつ た。

嘴は中央より先端は荅黑色にて基部は暗黄緑色，嘴の基部幅及厚さ共了才 
アシシギより瑤に太く，先端もアオアシシギ程反り上つていない。脚は前記

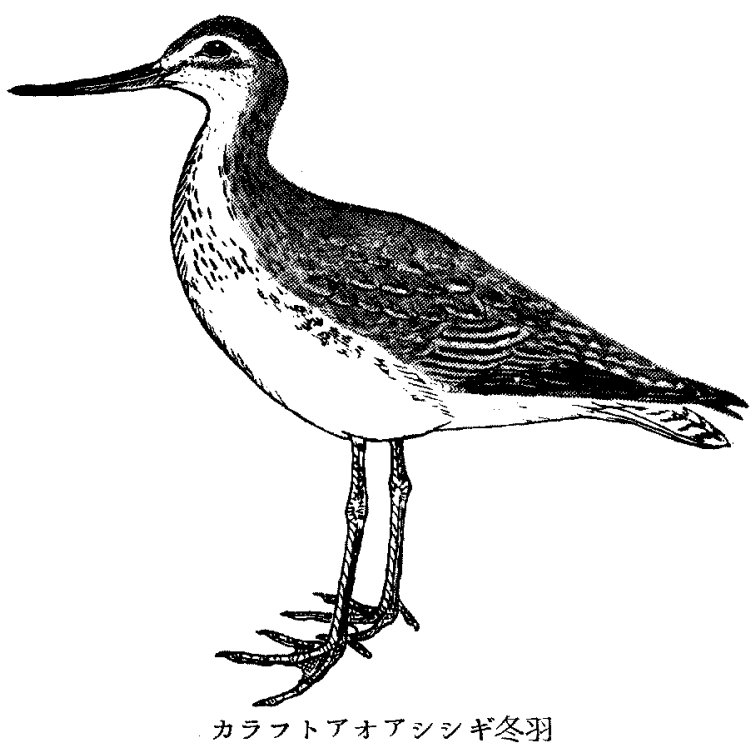
測定の通りアオアシシ ギより著しく短くキア シシギの脚よりむ著し く緑色を带びた黄緑色 である。内趾と外趾と は基部に於て膜にて中 趾と連続している。 習性

干潟上に単独にて居 り, 前面からは殆ど純 白色に見え且脚が短い 為, 当日附近に散見さ れたアジサシと混同す る位であつた。飛翔す ると腰の白色部は影著 であるが，アオアシシギ程脚長からず，むしろダイゼン位の大きさに見え る。声はきく事が出来なかつた。

食 性

イワガニ類の小片を検出する事が出来た。

本種も本邦には極めて稀に渡来するものであり従来僅に以下の記録がある に過ざない。

北海道：空蘭。1893 年 9 月。札幌博物館蔵。

本 州：神奈川県六郷川口。1915 年 9 月 23 日。黒田長䜹博士採集。 " : : 三重県度会郡宮川河口。1953 年 9 月 8 日。橋本太郎氏採集。 九 州: 薩摩 1918 年 9 月 15 日。鷹司信輔博士報。

之等の記録は何れも 9 月中に採集された秋期の渡りのものであるが，春期 の渡りの記録としては今回が初めてである。

一体日本に渡来するシギ・チドリ類の中で従来迷鳥又は檕めて稀に記録さ れた種類は，秋期の渡りに幼鳥である場合が圧倒的に多い。之は蕃殖期後の 
幼鳥が南下の梌中，何らかの都合で渡りの経路を誤つて日本列島を経由する ものと思われる。依つて，若し本種を日本への迷鳥とするなれば，今回の様 に蕃殖地への北上の途中に本種が渡来する事は極めて面白い例と思われる。

本種の蕃殖地に就ては「鳥」43号に黒田長禮博士が詳細に述べて居られ る通り，從来確実なる蕃殖地として知られたのは南樺太留多賀町附近のみで ある。東部シベリヤからカムチャツカ方面を長年に亘り，採集旅行をしたソ ビエツト連邦の鳥学者 Hans Johansen 博士も本種を自身野外にて観察した 事は一回もないと云つているし，又同じン連の鳥学者 S. A. Sladkov 氏の “Pticy SSSR” (Moskua 1951)に依れば”幼鳥は南樺太にて発見された事 がある。”とのみで詳細の記述はない。依つて岡田宜一氏の発見された留多 賀町附近の本種の蕃殖地は現在世界に知られた本種の㫿一の場所であると云 う事が出来よう。

同氏の報告に低るとその附近には比較的多数のものが見られる様である が，ソ連邦領内の各地に於ては本種は比較的稀なものであるらしい。前記 $\mathrm{A}$. S. Sladkov 氏に依孔ば下記の採集観察記録があるに過ぎない。

Okhotsk 河口

Gishiga 附近

Bering 島

Kamtchatcka の Avatcha 河河口

Sakhalin の Chaivo 潟

ウラジオストツク附近の Amur 湾

Amur 河河口の Langre 島

Ussuriland $の$ Khanka 湖
7 月

8 月 2 日。 3 羽钼察

5 月 22 日

5 月 27 日

q imm. 8 月 7 日

o ad. 8 月 8 日

1848 年 9 月 1 日及 12 日

(Vorobiew 氏に低る)

禋水二点 (5 月及 8 月)

標本二点 (8 月 27 日及 9 月 2 日)

本種は冬期には日本列島や交那大陸沿岸に沿い馬来・ビルマ・カルカツタ附 近に迄渡る様であるが，之等越冬地に於て採集された数も極めて粆い。及そ の経路にあたる各地の記録としては前記日本のもの以外に以下のものが知ら れている。

朝 鮮：咸鏡北道新浦 1912 年 9 月 13 日。1点 
台 湾：高雄州 1922 年 11 月 1 日。1 点 中華民国：福 州 1886 年 11 月 21 日。1 点 海南島 1890 年? 2 月 3 日。 2 点 ( 8 \%) 其他に 1,2 点が知られているのみ。

本種は標本を手にして見ると，アオアシシギに酷似している為に，野外に 於ても之と混同されてその記録が意外に尠いのではないかともいわれている が，筆者の経験に低れば，野外に於ても一見して，本種はアオアシシギとは 区別する事の出来る鳥である。にもかかわらず，本種の蕃殖地から越冬地え の経路と考えられる支那大陸に於ても，文日本列島に於ても従来の記録が意 外に题少所を見ると，この鳥は長途の渡りをするシギ・チドリ類の中では極 めて稀なるのの一つであると考えられる。又採集された標本の数から見てむ 日本列島と支那大陸とでは略同数であり，この何れ少が通常の渡りの経路と 考えられ，日本列島にあらわれるものは決して迷行したものではなく，年及 少数のものが，春秋の渡りに通過するものではないだらうか。(以下次号)

\section{コクマルガラス・ホオジロハクセキレイの新產地}

On new specimen records of Corvus monedula dauuricus and Motacilla alba leucopsis

田代道彌

Michiya Tashiro

神奈川目立小田原高校の生物教室には現在䄪 150 籄の鳥類剩製標本が所蔵 されている。筆者は本校在学中 1951 年より此等の䅺本の調査整理に着手 し, コクマルガラス・ホホジロハクセキレイの二標本を発見したので茲に報 告する。比等の標本は明治末期より大正時代に亘つて, 元当校教諭伊藤和貴 氏の蒐集せられたものが主である。調查を御援助下された松浦茂寿先生，近 藤正樹君に御礼申上げる。 